Human Rights Transformation in Practice 
PENNSYLVANIA STUDIES IN HUMAN RIGHTS

Bert B. Lockwood, Jr., Series Editor

A complete list of books in the series

is available from the publisher. 


\title{
Human Rights Transformation in Practice
}

\author{
Edited by \\ Tine Destrooper \\ and Sally Engle Merry
}

$\overline{\text { PENN }}$

UNIVERSITY OF PENNSYLVANIA PRESS

PHILADELPHIA 
Copyright (@) 2018 University of Pennsylvania Press

All rights reserved. Except for brief quotations used for purposes of review or scholarly citation, none of this book may be reproduced in any form by any means without written permission from the publisher.

\author{
Published by \\ University of Pennsylvania Press \\ Philadelphia, Pennsylvania 19104-4112 \\ www.upenn.edu/pennpress
}

Printed in the United States of America on acid-free paper

$109987 \begin{array}{lllllll}10 & 5 & 4 & 3 & 2 & 1\end{array}$

Library of Congress Cataloging-in-Publication Data

Names: Destrooper, Tine, editor. | Merry, Sally Engle, editor.

Title: Human rights transformation in practice / edited by Tine Destrooper and Sally Engle Merry.

Other titles: Pennsylvania studies in human rights.

Description: 1st edition. | Philadelphia : University of Pennsylvania Press, [2018] | Series:

Pennsylvania studies in human rights | Includes bibliographical references and index.

Identifiers: LCCN 2018015433 | ISBN 978-0-8122-5057-2 (hardcover : alk. paper)

Subjects: LCSH: Human rights. | Social justice. | Human rights and globalization.

Classification: LCC K3240 .H863 2018 | DDC 341.4/8-dc23

LC record available at https://lccn.loc.gov/2018015433 